\title{
A Review on Ultrasonic Catalytic Microbubbles Ozonation Processes: Properties, Hydroxyl Radicals Generation Pathway and Potential in Application
}

\author{
Xingaoyuan Xiong ${ }^{1}$, Bing Wang ${ }^{1,2, *}$, Wei Zhu ${ }^{3}$, Kun Tian ${ }^{1}$ and Huan Zhang ${ }^{1}$ \\ 1 School of Chemistry and Chemical Engineering, Southwest Petroleum University, Chengdu 610500, China; \\ xiongxgy@stu.swpu.edu.cn (X.X.); tiankun@stu.swpu.edu.cn (K.T.); zhanghuan@stu.swpu.edu.cn (H.Z.) \\ 2 Sichuan Provincial Key Laboratory of Environmental Pollution Prevention on Oil and Gas Fields and \\ Environmental Safety, Chengdu 610500, China \\ 3 Department of Quality, Security and Environmental Protection, PetroChina Tarim Oilfield Company, \\ Korla 841000, China; zhuwei-tlm@petrochina.com.cn \\ * Correspondence: wangb@swpu.edu.cn; Tel.: +86-028-83037300
}

Received: 29 November 2018; Accepted: 18 December 2018; Published: 24 December 2018

\begin{abstract}
Ozone-based advanced oxidant processes (AOPs) have attracted remarkable attention as an alternative and effective approach for mineralization of refractory organics to innocuous substances. Key issues for ozone-based AOPs mainly focused on how to enhance ozone mass transfer and improve the production of hydroxyl radicals. Unfortunately, great efforts have been made, though, the application of ozone-based AOPs still remained in the laboratory scale due to lack of understanding of mechanisms of these hybrid processes. Besides, obtaining the balance of economical-technical feasibility is a great challenge. Ultrasonic catalytic microbubbles ozonation could be considered as a promising method, despite that there are a few studies that addressed this potential technology. Therefore, in this review, summaries about ozone-based microbubbles process, ultrasonic catalytic ozonation process, and ultrasonic catalytic microbubbles ozonation process have been provided in order to give a novel prospective about these hybrid technologies. The main influential parameters, such as initial $\mathrm{pH}$, ozone dosage, intake flow rate, operating temperature, bubble size distributions, ultrasonic frequency, ultrasonic power density, and natural water constituents have also been well discussed. We truly hope that this paper will bring convenience to researchers that are devoted in the field of application of ozone-based AOPs for mineralizing refractory organics in wastewater.
\end{abstract}

Keywords: ozonation; microbubbles; ultrasonic; mass transfer; hydroxyl radicals; catalytic ozonation

\section{Introduction}

Ozonation is one of the most attractive and mature advanced oxidant processes (AOPs), which has been widely applied in the water/wastewater treatment accomplished by the removing of non-biodegradable compounds as well as refractory organics [1-6]. Ozone molecule with an oxidation potential of $2.07 \mathrm{~V}$ is capable of disinfection, color removal, and pollutants degradation in one single unit process [7-9]. Besides, $\mathrm{OH} \cdot(2.80 \mathrm{~V})$ generated through ozone decomposition in liquid phase is one of the major advantages [10].

Ozonation as well as ozone-based AOPs could be achieved by two routes:

- direct oxidation based on $\mathrm{O}_{3}$ molecule through electrophilic, nucleophilic and dipolar addition, all of which are comparatively slow and selective; and, 
- indirect oxidation based on $\mathrm{OH} \cdot$, which is capable of oxidizing refractory contaminants to $\mathrm{CO}_{2}$ and $\mathrm{H}_{2} \mathrm{O}$ in a fast and non-selective way.

In a single ozonation processes, the ozonation efficiencies were always confined by the relatively low mass transfer because of low solubility and stability of ozone in liquid phase [11,12]. With underused ozone existed in most processes, problems such as resource waste, a rather high treatment cost, and great harm to human health will emerge if ozone leakage occurs [13-16]. In addition, the selective reaction between ozone molecular and unsaturated bonds or amino groups in organics would lead to the formation of aldehydes and carboxylic acid, which is liable for the incomplete mineralization of pollutant [17-20]. For this reason, some modifications that could both/either enhance ozone mass transfer and/or promote $\mathrm{OH}$. generation are imperative.

Ozonation always proceeds by aeration. In this process, the adsorption of ozone into the liquid phase is controlled by liquid-film because the diffusion resistance of ozone molecule mainly exists in liquid phase [16]. The ozone-liquid transport rate mostly depends upon the interfacial area of ozone-liquid $[8,21,22]$. Thus, a comparatively smaller bubble diameter should benefit ozone mass transfer $[16,23,24]$. Microbubbles technology that could provide small bubbles with a respective diameter of $10-50 \mu \mathrm{m}$ has gained enormous attention $[25,26]$. Microbubbles are characterized by huge interfacial areas, low rising velocity and high inner pressure as compared with macrobubbles $[24,25,27]$, which are widely used in intensifying gas mass transfer into liquid phase [28-30]. The combination of ozone and microbubbles would be a promising method to enhance ozone mass transfer and is followed by an increase of degradation efficiency of pollutants.

Generation of $\mathrm{OH}$. (or other reactive oxygen species) as much as possible is an alternative way to accelerate ozonation efficiency. Ozone decomposition in liquid phase is a $\mathrm{pH}$ dependent process and it is always facilitated by the high concentration of $\mathrm{OH}^{-}$. OH. could be produced, even at acid medium in the presence of catalyst, which is defined as catalytic ozonation. Noteworthily, catalytic activity does not mean the formation of $\mathrm{OH} \cdot[19,31]$. It should be described as that the ozonation efficiency with a catalyst is higher than without the same catalyst at the same condition [31]. Catalytic ozonation could be categorized into two types in terms of catalyst: homogeneous (Mn(II), $\mathrm{Fe}(\mathrm{II}), \mathrm{Fe}(\mathrm{III})$, $\mathrm{Co}(\mathrm{II}), \mathrm{Cu}(\mathrm{II}), \mathrm{Zn}(\mathrm{II})$, and $\mathrm{Cr}(\mathrm{II})$, et al.) and heterogeneous (metal oxides, metals on supports, activated carbon, et al.) modes $[1,31]$. Heterogenous catalytic ozonation has been a hot issue of research in the last few years for the mineralization of recalcitrant. However, the mechanisms of these processes are still ambiguous, even controversial [17,32]. The exploitation of efficient catalysts is not a cost-effective process either. Disadvantages would limit the practical application of this technology. Hence, finding a modified ozonation process that possess both technical and economic feasibility is of important research challenge and obligatory.

The application of physical fields in ozonation process, such as Ultrasound $/ \mathrm{O}_{3}$ and $\mathrm{UV} / \mathrm{O}_{3}$, could be assigned to homogenous catalytic ozonation [33]. Amongst this, ultrasonic catalytic ozonation was considered as an attractive and promising AOP, because it conquers the major weaknesses of ozonation alone and ultrasound alone [34]. When compared with ultrasonic irradiation alone or ozonation alone process, additional $\mathrm{OH}$. generation in these processes is almost due to ozone self-decomposition that occurred with energy transfer from physical fields to the liquid phase. The synergistic effect of ultrasound and ozone have been proved by many groups [35], and it exhibited superior advantages among other ozone-based AOPs, such as no need of adding any other agents and operation feasible. It could be speculated that the combination of ozonation, microbubbles, and ultrasonic process would possess extraordinary performance in the ozone mass transfer and in the generation of $\mathrm{OH} \cdot$, thereby producing a better ozone utilization and a higher pollutant mineralization rate. Unfortunately, up to now, seldom efforts have been addressed in this field.

The main aims of this paper are to offer reviews on microbubbles, ultrasonic and ultrasonic catalytic ozonation process from the prospects of its mechanisms, and recent advances. Moreover, we focused on the combined technology-ultrasonic catalytic microbubbles ozonation from 
the point of enhancement mechanism and essential operating parameters, in order to provide a new accessible approach for wastewater treatment at the industrial scale.

\section{Ozonation-Based Microbubble Technology}

\subsection{Properties of Microbubble}

Microbubbles are defined as tiny bubbles with diameters of 10 to $50 \mu \mathrm{m}[25,36]$, which are capable of large gas-liquid interfacial area and relatively low rise velocity [28] (Figure 1) and they have exhibited superior properties of physical chemistry and size effects [26]. It has already been used in the fields of environmental engineering [37], biomedical engineering [38], and other industrial productions $[39,40]$. The efficacy of this technology depends on both diameter distribution and number density of microbubbles [28]. Thus, further understanding of microbubble generation mechanism to obtain better efficacy is important.

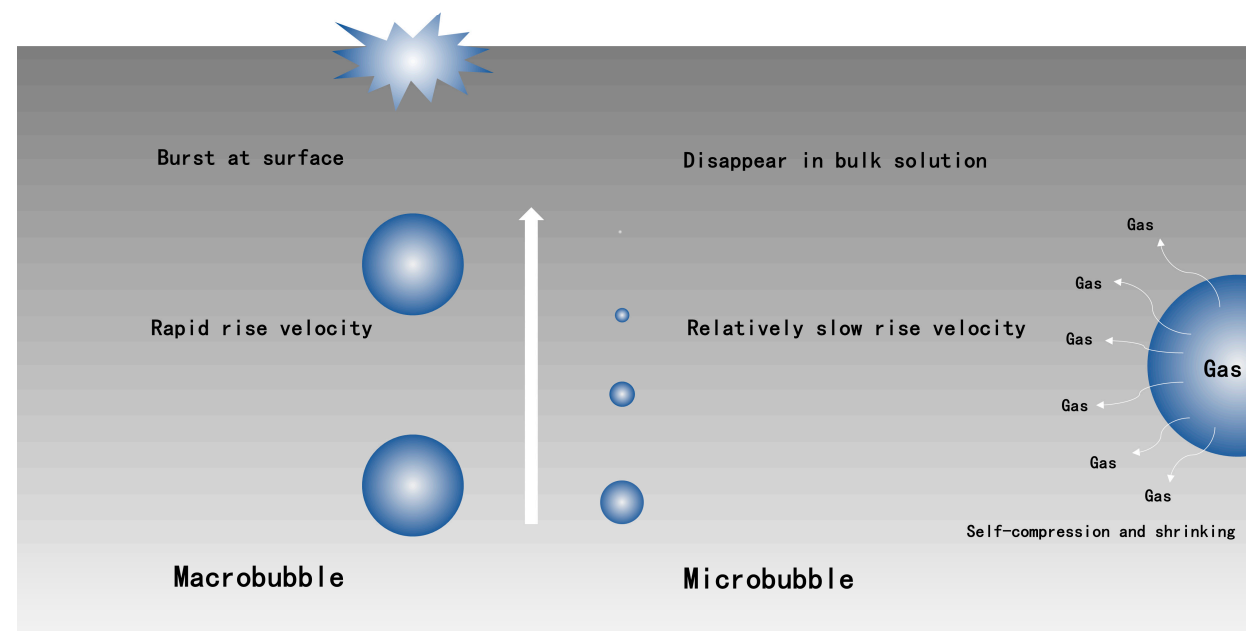

Figure 1. Compared schematic diagram of macrobubble and microbubble (reprinted with permission from (Free-Radical Generation from Collapsing Microbubbles in the Absence of a Dynamic Stimulus, [41]). Copyright (2019) Americam Chemical Society).

The most prominent property of microbubbles is that they could decrease in size and collapse liquid phase, while macrobubbles always burst at the surface [30]. High inner pressure, which is due to surface tension, is another key feature of microbubbles. The relationship between inner pressure and diameter could be described by the Young-Laplace equation:

$$
P=P_{I}+\frac{4 \delta}{d}
$$

where $P$ is inner pressure of microbubble, $P_{I}$ is liquid pressure, $\delta$ is surface tension of liquid phase, and $d$ is diameter of microbubble. Equation (1) indicates that the increased rate of inner pressure of microbubble could be inversely proportional to its diameter. The state of surrounding around microbubbles can be determined by a P-T diagram [30,42]. The formation process of hydrate nucleation is [30]: Firstly, microbubbles rise slowly in liquid phase, and shrinkage would occur at this point; and then, according to the Young-Laplace equation, inner pressure $(\mathrm{P})$ increases with shrinking bubble, meanwhile more amounts of gas dissolved in the vicinity of microbubble due to Henry's law; finally, hydrate nucleation would appear if the shrinkage stage of microbubble is sustained until near or over the supercooling limit. All of the studies that focused on microbubbles technology (Table 1) suggested that microbubble technology possesses an excellent property for gas absorption. According to Katsuhiko Muroyama et al. [26], bubbles with diameters that were smaller than approximately $50 \mu \mathrm{m}$ revealed extraordinary oxygen-absorption performance, and this could be 
owing to the self-compression and shrinking of microbubbles. A similar result has been observed by Kangning Yao et al. [24] that $\mathrm{K}_{\mathrm{L}}$ a values for microbubbles and conventional bubbles were $0.02905 \mathrm{~s}^{-1}$ and $0.02191 \mathrm{~s}^{-1}$, respectively, under a same operating condition.

Furthermore, bubble rising speed and surface charge are crucial parameters that could affect the properties of microbubbles. It was reported that microbubbles move towards the oppositely charged electrode invariably in the electrophoresis cell. The zeta potential of bubbles could be easily examined because the long stagnation of microbubbles in the liquid phase, and value of $-35 \mathrm{mV}$ was obtained in distilled water [43]. This means that the microbubbles-distilled water was "moderate stability" [7]. According to Takahashi M [29], the zeta potential of microbubbles is almost independent of the diameter, and in the terms of shrinkage, the zeta potential value would increase. This suggests that the quantity of electrical charge per unit area at the gas-liquid interface is invariable. Besides, other researchers have found that microbubbles are always negatively charged under a wide range of $\mathrm{pH}$ [25].

\subsection{Generation of Hydroxyl Radicals}

Free radicals, especially $\mathrm{OH} \cdot$, would be generated from collapsing microbubbles, which could non-selectively and quickly oxidize organics. The generation mechanism of free radicals has been studied by Takahashi M. and his group [44], they thought that the collapsing of microbubbles would take only tens of seconds, which is not sufficient to generate radical species by extremely high local temperature. Besides, the adiabatic compression would not happen in this condition. As the zeta potential increased during the process of bubble collapse, the possible pathway of the formation of free radicals has been proposed: first, some excess ions were trapped at the microbubble's interface; second, bubbles collapse leading to an abrupt disappear of gas-liquid interface, which allows for a drastic environmental change at this situ; finally, an instantaneous high density of ions occurred and free radicals generated. In this study, the presence of $\mathrm{OH} \cdot$ has been confirmed by EPR (electron spin resonance) spectroscopy. A same has been observed by others in 2015 [41] that $\mathrm{OH}$. existed in ozone-microbubbles, air-microbubbles, and ozone-macrobubbles systems. According to Alexander W. et al. [45], the types of reactive species generated through the plasma microbubble reactor were dependent on the temperature of plasma and the power source duty cycle.

The types of free radicals could be affected by the composition of ions. Alkyl radicals were produced via the collapse of nitrogen-microbubbles, while $\mathrm{OH}$ - were generated via collapse of both air-microbubbles and oxygen-microbubbles [39].

\subsection{Properties of Ozone-Based Microbubbles Technology}

In the area of ozone-based microbubble process, the advantages are mainly reflected in two aspects: (I) the intensification of ozone mass transfer; (II) the production of a large amount of $\mathrm{OH}$.

Ozone mass transfer in liquid phase can always be expressed by mass transfer coefficient, $\mathrm{K}_{\mathrm{L}} \mathrm{a}$, and could be described, as follows:

$$
\ln \left[\frac{C_{s}}{C_{S}-C}\right]=K_{L} a t
$$

where $C_{S}$ is equilibrium concentration of ozone and $C$ is dissolved ozone concentration. The $\mathrm{K}_{\mathrm{L}}$ a value is the slop of $\ln [C S /(C S-C)]$ versus t. Smaller bubbles could provide a larger gas-liquid contact area under a same input gas volume, resulting in a better mass transfer property. This has been confirmed by our previous study [46] that ozone microbubble with a smaller diameter would offer a higher ozone saturation concentration and a larger mass transfer coefficient.

Reactive oxygen species could be generated via two approaches:

- the shrinking and collapse of ozone microbubbles, which reactive oxygen species generated at interface of bubbles; and,

- the self-decomposition of ozone molecules, which occurs in bulk solution. 
Table 1. Overview on wastewater treatment through microbubbles technology

\begin{tabular}{|c|c|c|c|c|c|}
\hline System & $\begin{array}{c}\text { Wastewater/Organic/Simulated } \\
\text { Wastewater }\end{array}$ & $\mathrm{K}_{\mathrm{L}} \mathbf{a}$ & $\begin{array}{l}\text { Treatment Efficiency in } \\
\text { Optimal Condition }\end{array}$ & Conditions & Reference \\
\hline $\begin{array}{c}\text { Air-microbubbles, } \\
\text { Air-macrobubbles/conventional } \\
\text { bubbles }\end{array}$ & Tap water & $\begin{array}{l}\text { Air-macrobubbles: } 0.02191 \mathrm{~s}^{-1} \text {; } \\
\text { Air-microbubble: } 0.02905 \mathrm{~s}^{-1}\end{array}$ & - & Gas flow rate: $0.67 \mathrm{~L} \mathrm{~min}^{-1}$ & [24] \\
\hline Air-microbubbles & Phenol & - & Phenol removal: $60 \%(2 \mathrm{~h})$ & $\begin{array}{l}\text { Initial temperature: } 35^{\circ} \mathrm{C} ; \\
\text { Gas flow rate: } 0.5 \mathrm{dm}^{3} \mathrm{~min}^{-1} \\
\text { Initial pH: } 2.3\end{array}$ & [38] \\
\hline $\begin{array}{l}\text { Ozone-microbubbles, } \\
\text { Ozone-macrobubbles }\end{array}$ & $\begin{array}{c}\text { Acrylic fiber wastewater } \\
\text { (e.g., alkanes, aromatic } \\
\text { compounds, and other } \\
\text { refractory/bio-refractory organic } \\
\text { compounds, et al.) }\end{array}$ & $\begin{array}{l}\text { Ozone-microbubbles: } \\
0.3767 \mathrm{~min}^{-1} ; \\
\text { Ozone-macrobubbles: } \\
0.1732 \mathrm{~min}^{-1}\end{array}$ & $\begin{array}{c}\text { Ozone-microbubbles: CODcr removal: } \\
\text { 42\%; } \mathrm{NH}_{3}-\mathrm{N} \text { removal: } 21 \% ; \\
\mathrm{UV}_{254} \text { removal: } 42 \% ; \\
\text { Ozone-macrobubbles: CODcr removal: } \\
17 \% \text {; } \mathrm{NH}_{3}-\mathrm{N} \text { removal: } 12 \% ; \\
\mathrm{UV}_{254} \text { removal: } 7 \%\end{array}$ & $\begin{array}{l}\text { Initial temperature: } 20^{\circ} \mathrm{C} \text {; } \\
\text { ozone dosage: } 5 \mathrm{~g} \mathrm{~h}^{-1}\end{array}$ & [44] \\
\hline Ozone-microbubbles & $\begin{array}{l}\text { Fenitrothion (FT) } \\
\text { pesticide residues }\end{array}$ & - & $\begin{array}{l}\text { FT removal: } 35 \% \text {; } \\
\text { (cherry tomatoes were immersed into } \\
\text { solution for } 10 \mathrm{~min} \text { ) }\end{array}$ & Dissolve ozone concentration: $2.0 \mathrm{ppm}$ & [47] \\
\hline Ozone-microbubbles & Practical textile wastewater & $0.1072-0.4859 \mathrm{~min}^{-1}$ & $\begin{array}{l}\text { Color removal: } 80 \%(140 \mathrm{~min}) \text {; } \\
\text { COD removal: } 70 \% \text { (200 } \mathrm{min})\end{array}$ & $\begin{array}{c}\text { Initial temperature: } 19^{\circ} \mathrm{C} ; \\
\text { Gas flow rate: } 0.5 \mathrm{dm}^{3} \mathrm{~min}^{-1} \\
\text { Input ozone concentration: } 132 \mathrm{mg} \mathrm{dm}^{-3} \\
\text { Initial } \mathrm{pH}: 8.7\end{array}$ & [48] \\
\hline Ozone-microbubbles & dimethyl phthalate (DMP) & - & $\begin{array}{c}\text { DMP removal: } \\
99 \% \text { (300 s, initial SMP concentration: } \\
\left.0.052 \mathrm{~mol} \mathrm{~m}^{-3}\right) \\
95 \%(1800 \mathrm{~s} \text {, initial DMP concentration: } \\
\left.1.029 \mathrm{~mol} \mathrm{~m}^{-3}\right)\end{array}$ & $\begin{array}{l}\text { Gas flow rate: } 1.11 \mathrm{mg} \mathrm{s}^{-1} \\
\text { Initial } \mathrm{pH} \text {; }\end{array}$ & [49] \\
\hline
\end{tabular}


The generation of reactive oxygen species at the interface of ozone-liquid via the collapse of ozone microbubbles could be expressed by Figure 2 [50]: $\mathrm{H}^{+}$and $\mathrm{OH}^{-}$around microbubbles were trapped at microbubbles' surface in the process of shrinking; and, the diameter of bubbles continued to shrink until collapse; meanwhile, reactive oxygen species, especially $\mathrm{OH} \cdot$, were produced due to the sudden disappear of the surface. Furthermore, self-decomposition of ozone molecules in liquid phase, triggering the formation of $\mathrm{OH}$, has no difference with the conventional ozonation process. The extra $\mathrm{OH} \cdot$ produced by microbubble collapse has a high benefit on the oxidation of refractory organic matters. The collapse of microbubbles also induces local turbulences, which could facilitate the contact between $\mathrm{O}_{3} / \mathrm{OH} \cdot$ and pollutants, and is followed by an intensification of organic mineralization.

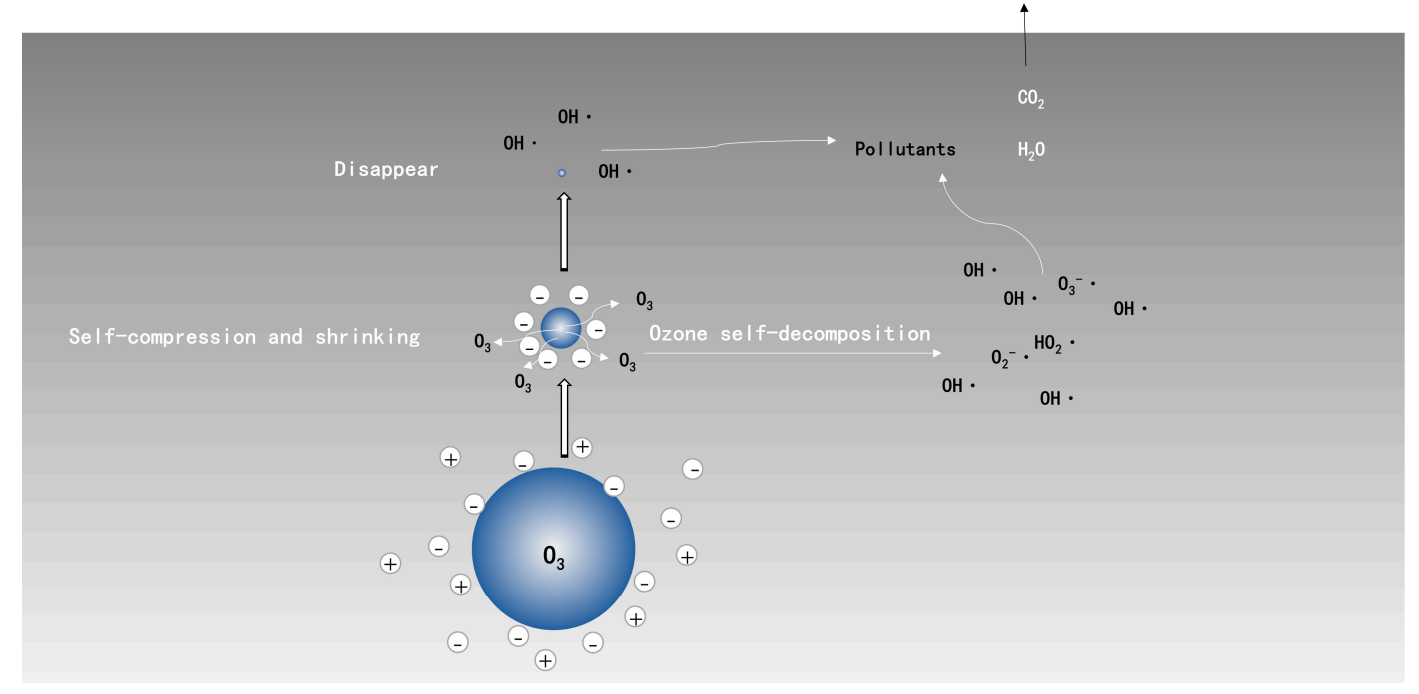

Figure 2. Schematic diagram of ozone-microbubble in liquid phase.

Tianlong Zheng et al. [41] made a comparison between macrobubble-ozonation process and microbubble-ozonation process on the degradation of wet-spun acrylic fiber wastewater. The results showed that, when compared with microbubble ozonation, the microbubble could efficiently improve the removal efficiency of CODcr, $\mathrm{NH}_{3}-\mathrm{N}$, and $\mathrm{UV}_{254}$ by $25 \%, 21 \%$, and $42 \%$, respectively. Biodegradability has also been improved. This phenomenon could be ascribed to the production of more $\mathrm{OH}$., which has been measured by 3D-EEM (three-dimensional excitation-emission matrix fluorescence spectroscopy). According to H. Ikeura et al. [47], ozone-microbubbles also specialized in the removal of residual pesticides as compared with ozone-millibubbles. Li Pan et al. [51] found difference on DBPs (degradation by-products) generation between microbubbles ozonation and conventional bubbles ozonation and proved that most bromate formation was the result of $\mathrm{O}_{3}$ molecular direct oxidation, which could be limited by the addition of ammonia. An enhanced color removal efficacy has also been observed [48,52]. According to literatures [45,53], a novel plasma dielectric barrier discharge (DBD) microbubble reactor was designed, and ozone-microbubbles that were produced by this reactor could effectively oxidize toxic cyanobacterial species to harmless productions and can also be used for the pretreatment of lignocellulosic biomass.

An indirect method for $\mathrm{OH}$ - measurement was firstly proposed by Elovitz M.S. and Gunten U.V. [54], where pCBA ( $\rho$-chlorobenzoic acid) was selected as radical probe due to the low reaction activity with the $\mathrm{O}_{3}$ molecule as compared to $\mathrm{OH}$. for the rate constants between PCBA and $\mathrm{O}_{3}$ molecule/OH. are 0.15 and $5 \times 10^{9} \mathrm{dm}^{3} \mathrm{~mol}^{-1} \mathrm{~s}^{-1}$, respectively. In-depth research for measuring the amount of $\mathrm{OH}$. in ozone microbubbles process has been conducted by Snigdha Khuntia et al. [10]. In this paper, $\mathrm{O}_{3}$ exposure, $\mathrm{OH}$ - exposure, and Rct values which indicate the ratio of $\mathrm{OH}$ - - exposure and $\mathrm{O}_{3}$-exposure, were calculated, and the results showed that the values of $\mathrm{O}_{3}$ exposure and $\mathrm{OH}$. exposure in acid medium were higher than neutral/basic medium. However, a remarkable increase 
was observed when $\mathrm{pH}$ value exceeds 10. It is a tremendous advantage for microbubbles ozonation process, because the amount of $\mathrm{OH}$ - in acid treated medium could be negligible in macrobubbles ozonation processes. The generation of $\mathrm{OH}$ - at $\mathrm{pH} 7$ has been reported by Abdisa Jabesa [49], which was responsible for the degradation of DMP (dimethyl phthalate). This indicates that the application range of ozone-based AOPs would be expanded, because $\mathrm{OH}$. can even be produced in the acid medium. In many cases, industrial effluents are usually acid liquid.

\section{Ultrasonic Catalytic Ozonation}

\subsection{Ultrasonic Technology}

Ultrasound has been widely used in waste water treatment for the removal of aromatic compounds, chlorinated aliphatic compounds, herbicides, pesticides, azo dyes, and bacteria, et al. [55-62]. This is due to the fact that ultrasound is able to yield $\mathrm{OH}$ - (Equation (3)) in the liquid phase by decomposing water molecule [63-65]. Other free radicals were produced simultaneously in this process such as $\mathrm{H}, \mathrm{HOO}$ (Equations (3) and (4)). Moreover, according to Fitzgeral, $\mathrm{H}_{2} \mathrm{O}_{2}$ (Equation (5)) would also be formed in this process [66]. The formation of $\mathrm{H}_{2} \mathrm{O}_{2}$ would also benefit pollution degradation. In short, this process could be described as follows [56]:

$$
\begin{aligned}
& \mathrm{H}_{2} \mathrm{O} \stackrel{())))}{\longrightarrow} \mathrm{H} \cdot+\mathrm{OH} \text {. } \\
& \mathrm{H} \cdot+\mathrm{O}_{2} \stackrel{))))}{\longrightarrow} \mathrm{HOO} \text {. } \\
& 2 \mathrm{OH} \cdot \longrightarrow \mathrm{H}_{2} \mathrm{O}_{2}
\end{aligned}
$$

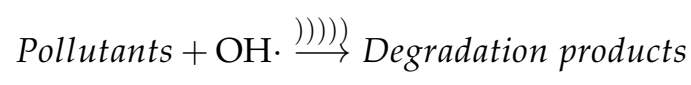

$$
\begin{aligned}
& \text { Pollutants }+ \text { HOO. } \stackrel{())))}{\longrightarrow} \text { Degradation products }
\end{aligned}
$$

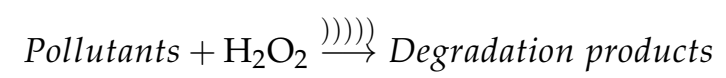

In addition, it is noteworthy that $\mathrm{H}_{2} \mathrm{O}_{2}$ could be decomposed to generate $\mathrm{HO}$ in the presence of acoustic cavitation [67]:

$$
\mathrm{H}_{2} \mathrm{O}_{2} \stackrel{\text { Cavitation }}{\longrightarrow} 2 \mathrm{HO} \text {. }
$$

The application of ultrasound in AOPs for enhancing the mass transfer efficiency and/or chemical reactions is defined as "sonochemistry" [68,69]. Sonochemistry is always performed accompanied by acoustic cavitation [70,71], which refers to the process of cavitation in bubbles formation, growth, and collapse [69,72]. It could be explained by the hot spot theory that when ultrasound applied in liquid phase, vibrations of molecules due to ultrasonic energy would result in a decreasing liquid static pressure, and cavitation bubbles arise until liquid pressure below the vapor pressure abruptly $[59,69]$. It should be emphasized that the shrinkage rate of cavitation bubbles is extremely quick than microbubbles [25]. The implosion of cavitation bubbles leading to an enormous concentration of energy conversion from liquid motion (kinetic energy) into bubble content (heating energy), resulting in a "hot spot", where $5200 \mathrm{~K}$ in bubble gas phase and $1900 \mathrm{~K}$ in gas-liquid interface [73-75], followed by an extraordinary rapid cooling immediately, which allows for both chemical and physical effects [70,76-80]:

- chemical effect: this extreme circumstance would provide a specific pathway for chemical reactions happen; the generated $\mathrm{OH}$ - by pyrolysis inside the cavity and near the interface of the cavity would oxidize organic matters non-selectively; and,

- physical effect: the severe turbulence in liquid that is caused by cavitation bubbles could benefit the mixing of target organics and oxidizing agents/catalysts. 


\subsection{Properties of Ozone-Based Microbubbles Technology}

Cavitation is an effective way to reduce ozone mass transfer resistance by causing turbulence in bulk solution and microcirculation surrounding cavitation bubbles, which is advantageous for ozone mass transfer, and is followed by an increased ozone dissolve concentration [46,78,81-83]. Meanwhile, molecular ozone was decomposed into oxygen molecule and oxygen atom in liquid phase under ultrasonic irradiation, and followed by $\mathrm{OH}$. formation as a result of reaction between oxygen atom and water molecule. This process could be described as [70]:

$$
\begin{gathered}
\mathrm{O}_{3} \stackrel{()))}{\longrightarrow} \mathrm{O}+\mathrm{O}_{2} \\
\mathrm{O}+\mathrm{H}_{2} \mathrm{O} \longrightarrow 2 \mathrm{HO} .
\end{gathered}
$$

In the ultrasonic catalytic ozonation process, $\mathrm{OH}$. are expected to generated by approaches that (i) self-decomposition of $\mathrm{O}_{3}$ (in basic medium); (ii) thermal decomposition of $\mathrm{H}_{2} \mathrm{O}$; and, (iii) reaction between $\mathrm{O}$ (atomic) and $\mathrm{H}_{2} \mathrm{O}$.

The enhanced ozone mass transfer and production of large amount of $\mathrm{OH}$ - in bulk solution, indicating that the mineralization efficiency of recalcitrant organics could be further improved in a same operating condition as compared with ozonation alone or ultrasound alone. Zhiqiao He. et al. [84] reported the color decay of C.I. Reactive Black 5 by $\mathrm{O}_{3} /$ Ultrasound, and results showed that this process followed pseudo-first-order kinetics. Another dye has been studied by Yongjun Shen et al. [85], and the degradation efficiency of active red X-3B by ozone, ultrasound, and ozone/ultrasound follow the order of $\mathrm{O}_{3} /$ Ultrasound $>\mathrm{O}_{3}>$ Ultrasound. Research conducted by Amna M. et al. [86] proved that this hybrid technology has a potential of water disinfection, which was in accordance with the literature provided by Jyoti K. K. et al. [72], and the optimal synergetic factor (E) reaches 1.42. A pilot scale study has been conducted by Guodong Ji et al., [87], of which the results showed that the value of kinetic rate constant has been improved from $1.1 \times 10^{-3} \mathrm{~min}^{-1}$ (ozonation alone) to $49.9 \times 10^{-3} \mathrm{~min}^{-1}$ (ultrasonic catalytic ozonation). The relationship between oxidation efficiency, $\mathrm{OH} \cdot$, and ultrasonic fields was revealed by Lei Zhao et al. [34] that multiple-field of ultrasound (28 kHZ) could intensify the removal efficiency of nitrobenzene and a positive correlation between the enhancement degree and the amount of ultrasound field, both of which could be ascribed to the enhanced ozone mass transfer and accelerated initiation $\mathrm{OH}$ - concentration. In most studies, additional $\mathrm{OH}$ - plays a major role in pollutants removal; however, according to WanQian Guo et al. [88], direct oxidation via ozone molecular was responsible for sulfamethoxazole degradation. The degradation efficiency of acephate and degradation products have also been studied [89].

\section{Ultrasonic Catalytic Microbubbles Ozonation Process}

\subsection{Properties of This Hybrid Technology and Generation Pathway of Hydroxyl Radicals}

The hybrid technology of $\mathrm{O}_{3} /$ Ultrasonic has been reported by several researchers (Table 2); however, only few studies have focused on the combined application of ultrasound and ozone-microbubbles (Table 3). The first attempt has been and made by $\mathrm{Zheng} \mathrm{Xu}$ et al. [35], in which the 1, 4-Dioxane has been selected as target pollutant. According to this research, the synergistic effect on reaction rate constant could be owing to the formation of additional $\mathrm{OH} \cdot$, the increasing ultrasonic input power, and the higher ozone concentration.

This hybrid technique employs the combination of ozonation, ultrasound, and microbubbles process, leading to both an improved ozone mass transfer and an increased level of $\mathrm{OH}$. in the liquid phase, hence the pollutants removal rate would be significantly improved, especially refractory pollutants and biorefractory compounds. According to our previous study on ultrasonic catalytic microbubbles ozonation process [46], an increment of $0.194 \mathrm{~min}^{-1}$ of $\mathrm{K}_{\mathrm{L}}$ a value was observed after the application of ultrasonic power, and both the degradation and mineralization efficiency of SMP 
(sulfonated phenolic resin) were intensified as expected, which could be ascribed to both an improved ozone mass transfer coefficient and the generation of extra $\mathrm{OH}$.

Both the reduced ozone mass transfer resistance in virtue of acoustic cavitation and the final stage of microbubble shrinkage would make a contribution to the dissolution of more ozone, which may render higher ozone saturation concentrations. Furthermore, $\mathrm{OH}$. could be produced via (i) ozone self-decomposition; (ii) water thermal decomposition; (iii) atomic $\mathrm{O}$ react with $\mathrm{H}_{2} \mathrm{O}$ molecular; and, (iv) the collapse of microbubbles. This mutual promotion process exhibits some unique technology superiorities, such as reduced reaction time and elevated mineralization rate.

\subsection{Typical Experimental Operating Parameters}

\subsubsection{Initial $\mathrm{pH}$}

The initial $\mathrm{pH}$ of reaction medium is usually considered as a prime parameter in ozone-based AOPs, because it could alter both ozone self-decomposition rate and ozonation pathway. As generally recognized, basic environment facilitates the mineralization of recalcitrant chemicals as a result of indirect oxidation via $\mathrm{OH}$ - in ozonation processes [90-93]. Whereas, acid medium always benefits the formation of $\mathrm{OH}$. in microbubbles systems [25]. Hence, experiments must be conducted to clarify the kinetics and mechanism of ozone reactions and optimize $\mathrm{pH}$ to obtain $\mathrm{OH}$. as much as possible.

\subsubsection{Ozone Dosage}

Ozone dosage could directly affect dissolved ozone concentration, ozone saturation concentration, and production of $\mathrm{OH} \cdot$, and then affect ozone-liquid mass transfer, ozone utilization rate, and removal rate of contaminations. Ozone utilization rate could be calculated by equation:

$$
\mathrm{O}_{3} \text { utilization }[\%]=\frac{\mathrm{O}_{3(\text { input })}[\mathrm{mg} / L]-\mathrm{O}_{3(\text { off gas })}[\mathrm{mg} / L]}{\mathrm{O}_{3(\text { input })}[\mathrm{mg} / \mathrm{L}]} \times 100
$$

This means that higher ozone-liquid mass transfer may not coincide with higher $\mathrm{O}_{3}$ utilization rate, because $\mathrm{K}_{\mathrm{L}}$ a is a function of ozone saturated concentration and time, while ozone utilization rate is associated with other conditions (e.g., ozone-self decomposition rate). We could speculate that, in strong basic medium, $\mathrm{K}_{\mathrm{L}}$ a value is much lower than acid medium, but the $\mathrm{O}_{3}$ utilization rate is just the reverse. This is because ozone is unstable in the presence of an ample amount of $\mathrm{OH}^{-}$and could decomposed into $\mathrm{OH}$. rapidly [92-94], which dramatically reduces ozone saturated concentration, and eventually, a decreased $\mathrm{K}_{\mathrm{L}}$ a value. However, the basic condition may result in higher ozone concentration gradient between gas and liquid phase, which is the main driving force for ozone mass transfer. Thus, more ozone molecular could be dissolved into liquid phase, consequently a higher $\mathrm{O}_{3}$ utilization rate. Hence, it is necessary to take both the ozone mass transfer coefficient and $\mathrm{O}_{3}$ utilization into consideration in practical application. To date, $\mathrm{O}_{3}$ utilization has seldom been assessed. On the other hand, excessive ozone might impede organic mineralization [95]:

$$
\begin{aligned}
& 2 \mathrm{OH} \cdot+\mathrm{O}_{3} \longrightarrow 2 \mathrm{O}_{2}+\mathrm{H}_{2} \mathrm{O} \\
& \mathrm{OH} \cdot+\mathrm{HO}_{2} \cdot \longrightarrow \mathrm{H}_{2} \mathrm{O}+\mathrm{O}_{2}
\end{aligned}
$$


Table 2. Overview on wastewater treatment through ultrasonic catalytic ozonation process.

\begin{tabular}{|c|c|c|c|c|c|}
\hline System & $\begin{array}{c}\text { Wastewater/Organic/Simulated } \\
\text { Wastewater }\end{array}$ & $\mathrm{K}_{\mathrm{L}} \mathbf{a}$ & $\begin{array}{l}\text { Treatment Efficiency in } \\
\text { Optimal Condition }\end{array}$ & Conditions & Reference \\
\hline $\mathrm{O}_{3} /$ Ultrasound & Nitrobenzene & $\begin{array}{c}\mathrm{O}_{3} / \text { Ultrasound: } 0.24-0.43 \mathrm{~min}^{-1} \\
\mathrm{O}_{3}: 0.20 \mathrm{~min}^{-1}\end{array}$ & $\begin{array}{l}\text { Nitrobenzene removal: } 60.9 \% \\
\text { TOC removal: } 88.8 \%\left(30 \mathrm{~min}^{-1} \text { initial }\right. \\
\left.\text { concentration: } 50 \mu \mathrm{g} \mathrm{L}^{-1}\right)\end{array}$ & $\begin{array}{c}\text { Initial temperature: } 20^{\circ} \mathrm{C} ; \\
\text { Total applied ozone: } 1.2 \mathrm{mg} \mathrm{L}^{-1} \text {; } \\
\text { Initial pH: } 6.85 ; \\
\text { Ultrasonic power density: } 38.5 \mathrm{~W} \mathrm{~L}^{-1} \text {; } \\
\text { Ultrasonic power frequency: } 28 \mathrm{kHz} \text {; } \\
\text { Ultrasonic fields: } 4\end{array}$ & [34] \\
\hline $\mathrm{O}_{3} /$ Ultrasound & Triazophos & - & $\begin{array}{l}\text { Triazophos removal: } 52.4 \%(90 \mathrm{~min}, \\
\text { initial concentration: } 20 \mathrm{ppm} \text { ) }\end{array}$ & $\begin{array}{c}\text { Initial temperature: } 37^{\circ} \mathrm{C} ; \\
\text { Ozone intake flow rate: } 400 \mathrm{mg} \mathrm{h}^{-1} \text {; } \\
\text { Initial } \mathrm{pH}: 3.2 ; \\
\text { Ultrasonic power: } 1500 \mathrm{~W} ; \\
\text { Ultrasonic power frequency: } 40 \mathrm{kHz}\end{array}$ & [62] \\
\hline $\mathrm{O}_{3} /$ Ultrasound & Benzophenone-3 & - & - & $\begin{array}{c}\text { Initial temperature: } 25^{\circ} \mathrm{C} ; \\
\text { Ozone intake flow rate: } 3500 \mathrm{mg} \mathrm{h}^{-1} \text {; } \\
\text { Ultrasonic power: } 50 \mathrm{~W} ; \\
\text { Ultrasonic power frequency: } 160 \mathrm{kHz}\end{array}$ & [65] \\
\hline $\mathrm{O}_{3} /$ Ultrasound & C.I. Reactive Black 5 & - & $\begin{array}{c}\text { Color removal: } \\
100 \%(4 \mathrm{~min} \text {, initial concentration: } 100 \\
\left.\mathrm{mg} \mathrm{L}^{-1}\right) \\
82 \%\left(4 \mathrm{~min}^{5} 500 \mathrm{mg} \mathrm{L}^{-1}\right)\end{array}$ & $\begin{array}{l}\text { Initial temperature: } 35^{\circ} \mathrm{C} \\
\text { Ozone concentration: } 1 \mathrm{mg} \mathrm{L} \\
\text { Ultrasonic power density: } 88 \mathrm{~W} \mathrm{~L}^{-1}\end{array}$ & [84] \\
\hline $\mathrm{O}_{3} /$ Ultrasound & Reactive red X-3B dye & $0.43 \mathrm{~min}^{-1}$ & Dye removal: $99.2 \%$ (6 min) & $\begin{array}{l}\text { Initial concentration: } 100 \mathrm{mg} \mathrm{L}^{-1} \text {; } \\
\text { Ozone flux: } 40 \mathrm{~L} \mathrm{~h}^{-1} ; \\
\text { Initial pH: } 6.52 ; \\
\text { Ultrasonic power density: } 200 \mathrm{~W} \mathrm{~L}^{-1}\end{array}$ & [85] \\
\hline $\mathrm{O}_{3} /$ Ultrasound & Bacteria & - & Reduction of live cells: $99 \%$ ( $4 \mathrm{~min}$ ) & $\begin{array}{c}\text { Initial temperature: } 25^{\circ} \mathrm{C} \\
\text { Ozone dosage: } \mathrm{g} \mathrm{h}^{-1} ; \\
\text { Ultrasonic power: } 100 \mathrm{Watt} \text { each } \\
\text { Ultrasonic power frequency: } 612 \mathrm{kHz}\end{array}$ & [86] \\
\hline $\mathrm{O}_{3} /$ Ultrasound & Sulfamethoxazole (SMX) & - & SMX removal: $100 \%$ & $\begin{array}{c}\text { Ozone dosage: } 3 \mathrm{~g} \mathrm{~h}^{-1} \\
\text { Initial pH: } 9 ; \\
\text { Ultrasonic power density: } 600 \mathrm{~W} \mathrm{~L}^{-1} \text {; } \\
\text { Initial temperature: } 25^{\circ} \mathrm{C} ;\end{array}$ & [88] \\
\hline $\mathrm{O}_{3} /$ Ultrasound & Acephate & - & Acephate removal: $87.6 \%$ (60 min) & $\begin{array}{l}\text { Ozone intake flow rate: } 3500 \mathrm{mg} \mathrm{h}^{-1} \text {; } \\
\text { Ultrasonic power: } 50 \mathrm{~W} ; \\
\text { Ultrasonic power frequency: } 160 \mathrm{kHz} \\
\text { Initial temperature: } 35^{\circ} \mathrm{C} ;\end{array}$ & [89] \\
\hline $\mathrm{O}_{3} /$ Ultrasound & potassium ferrocyanide (KFC) & - & KFC removal: $82.41 \%$ (90 min, 200 ppm) & $\begin{array}{l}\text { Ozone dosage: } 400 \mathrm{mg} \mathrm{h}^{-1} \\
\text { Ultrasonic power: } 1 \mathrm{~kW} ; \\
\text { Ultrasonic power frequency: } 25 \mathrm{kHz}\end{array}$ & [96] \\
\hline
\end{tabular}


Table 3. Overview on wastewater treatment through ultrasonic catalytic microbubbles ozonation process.

\begin{tabular}{|c|c|c|c|c|c|}
\hline System & $\begin{array}{c}\text { Wastewater/Organic/Simulated } \\
\text { Wastewater }\end{array}$ & $\mathrm{K}_{\mathrm{L}} \mathbf{a}$ & $\begin{array}{l}\text { Treatment Efficiency in } \\
\text { Optimal Condition }\end{array}$ & Conditions & Reference \\
\hline Ozone-microbubbles/Ultrasound & 1, 4-Dioxane & - & $\begin{array}{l}\text { Reaction rate constant: } \\
\text { ozone-microbubbles/Ultrasound } \\
\text { process: } 6.3 \times 10^{-3} \mathrm{~min}^{-1}\end{array}$ & $\begin{array}{c}\text { Ozone dosage: } 101.5 \mathrm{mg} \mathrm{L}^{-1} \\
\text { Ultrasonic power: } 150 \mathrm{~W} ; \\
\text { Ultrasonic power frequency: } 490 \mathrm{kHz}\end{array}$ & [35] \\
\hline Ozone-microbubbles/Ultrasound & Sulfonated phenolic resin (SMP) & $\begin{array}{c}\text { Ozone-microbubbles: } \\
0.438 \mathrm{~min}^{-1} \\
\text { Ozone-microbubbles/Ultrasound: } \\
0.632 \mathrm{~min}^{-1}\end{array}$ & $\begin{array}{l}\text { SMP removal: 50\% (5 min) } \\
\text { TOC removal: } 75 \%(120 \mathrm{~min})\end{array}$ & $\begin{array}{l}\text { Initial temperature: room temperature } \\
\text { Ozone intake flow rate: } 300 \mathrm{~L} \mathrm{~h}^{-1} \text {; } \\
\text { Ultrasonic power: } 1000 \mathrm{~W} ; \\
\text { Ultrasonic power frequency: } 20 \mathrm{kHz}\end{array}$ & [46] \\
\hline
\end{tabular}




\subsubsection{Intake Flow Rate}

Ozone intake flow rate is related with state of liquid phase, bubble size distributions, and bubble rise velocity. An increasing gas intake flow rate would lead to severe turbulence of the liquid phase and less coalescence of small bubbles, which could expedite ozone-liquid mass transfer. However, the faster bubble rise velocity indicates the shorter ozone-liquid contact time, resulting in a lower mass transfer eventually. An appropriate intake flow rate should to obtain maximum utilization of ozone is crucial.

\subsubsection{Operating Temperature}

Temperature is another important factor that can influence the ozone solubility, ozone self-decomposition rate, kinetics between oxidants $\left(\mathrm{O}_{3}\right.$ and/or $\left.\mathrm{OH} \cdot\right)$ and organics in liquid phase, and vapor content in cavitation bubble. The increase of temperature could decrease ozone solubility (Equation (15)) $[95,97,98]$ and $\mathrm{OH} \cdot$ production, which are based on the implosion of cavitation bubble through increased bubble vapor content and declined collapse pressure $[99,100]$. Meanwhile, a rising operating temperature expedites the conversion of $\mathrm{O}_{3}$ to $\mathrm{OH}$. and then the degradation rate of pollutants increased [101,102]. Those contradictory results above indicate that the optimal temperature for ozone mass transfer and ozone utilization in practical application should be measured to obtain a better understanding of this hybrid process. In most studies, room temperature $\left(25^{\circ} \mathrm{C}\right)$ was found to be the best choice [95].

$$
\log \left(\frac{\mathrm{H}_{\mathrm{O}_{3}}}{\mathrm{kPam}^{3} \mathrm{~mol}^{-1}}\right)=5.12-\frac{1230}{\mathrm{~T}(\mathrm{~K})}
$$

\subsubsection{Bubbles Size Distribution}

The measurement of diameter distribution of microbubbles is indispensable as gas-liquid interface area plays a vital role in ozone mass transfer. The peak of bubble diameter distribution curve located in a smaller value, which indicates a smaller mean diameter of bubbles, moreover, a wider peak width reveals a larger proportion of small diameter bubbles, both of which advances ozone mass transfer due to a larger ozone-liquid contact area with the same ozone volume. According to Young-Laplace equation (Equation (1)), the internal pressure of a bubble with diameter of $1 \mu \mathrm{m}$ is four times higher than atmospheric pressure [25].

\subsubsection{Ultrasonic Frequency}

Ultrasonic performance is closely associated with ultrasonic frequency. According to literature $[103,104]$, as compared with high ultrasonic frequency, low frequency creates strong shear and mechanical forces that are conductive to the sonochemistry effect and followed with a better degradation efficacy of pollutant. $20-40 \mathrm{kHz}$ frequencies were widely used according to report [104].

\subsubsection{Ultrasonic Power Density}

Ultrasound input power density $\left(\mathrm{W} / \mathrm{L}\right.$ or $\left.\mathrm{W} / \mathrm{cm}^{2}\right)$ is an important parameter in deciding the number of cavitation bubbles [105] and evaluating energy consumption [106]. An increase in ultrasonic power density always leads to a higher ozone saturation concentration, ozone mass transfer efficiency, and degradation efficacy of organics [106-109]. According to our previous study [46], the $\mathrm{K}_{\mathrm{L}}$ a value dropped with excessive evaluated ultrasonic density, and this phenomenon could be ascribed to increased coalescence odds of ozone bubbles and temperature. On the other hand, excessive power density would result in the augmentation of overall costs, which is sensitive in practical application.

\subsubsection{Natural Water Constituents}

Natural water constituents refer to anions (e.g., $\mathrm{Cl}^{-}, \mathrm{HCO}_{3}{ }^{-}, \mathrm{CO}_{3}{ }^{2-}, \mathrm{SO}_{4}{ }^{2-}$, and $\mathrm{PO}_{4}{ }^{3-}$ ), cations (e.g., $\mathrm{Ca}^{2+}, \mathrm{Mg}^{2+}$ ) and natural organic matter (NOM). Effects of those ions on pollutants removal 
in ozone-based AOPs are of great value to investigate. In basic medium, $\mathrm{HCO}_{3}{ }^{-}$and $\mathrm{CO}_{3}{ }^{2-}$ acting as radical scavengers that can react with $\mathrm{OH}$ - (Equations (16) and (17)), which significantly hindered mineralization of pollutants. Phosphates present different forms at different $\mathrm{pHs}$, such as $\mathrm{H}_{3} \mathrm{PO}_{4}, \mathrm{H}_{2} \mathrm{PO}_{4}{ }^{-}, \mathrm{HPO}_{4}{ }^{2-}$, and $\mathrm{PO}_{4}{ }^{3-}$. The presence of phosphate ions in bulk solution would inhibit the production of free radicals via occupied active site on surface of heterogenous catalyst $[17,110]$.

$$
\begin{gathered}
\mathrm{OH} \cdot+\mathrm{HCO}_{3}^{-} \longrightarrow \mathrm{CO}_{3}^{--}+\mathrm{H}_{2} \mathrm{O} . \\
\mathrm{OH} \cdot+\mathrm{CO}_{3}^{2-} \longrightarrow \mathrm{CO}_{3}^{--}+\mathrm{OH}^{-}
\end{gathered}
$$

\section{Conclusions}

The instability and low solubility of ozone molecular in liquid phase impedes the further application of ozone and ozone-based technology in the field of wastewater treatment. Several achievements in ozone-based AOPs fields have been undertaken by researchers to obtain an improved ozone utilization rate. The ultrasonic catalytic microbubbles ozonation process can be considered as an appropriate way for improving ozone mass transfer and the conversion of ozone to $\mathrm{OH}$., which results in an increased degradation of recalcitrant contaminant in bulk solution. The oxidation performance of this hybrid process is affected by several typical parameters; thus, if the operating conditions are properly selected and optimized based on experiments, a complete mineralization of pollutant with receptible ozone consumption would be accomplished. Receptible ozone consumption means high ozone utilization, including high ozone transfer and a large amount of $\mathrm{OH} \cdot$ production.

This technology characterized by simplicity, lower expenses, ease of operation, and no reservoir pollutant has potential in the treatment of real wastewater and industrial application. However, the subject of ultrasonic catalytic microbubble ozonation is still a long way from the laboratory scale to industrial application. Some scale up strategies are given, as follows:

1. the economic feasibility of ultrasonic-assisted microbubble ozonation process at industrial scale should be verified;

2. enhancement mechanism of this technology is still unclear. Therefore, in-depth studies should be conducted. To accelerate degradation efficacy and improve ozone utilization in the field of ozone-based AOPs, parameters such as: ozone mass transfer efficiency, ozone utilization, ozone decay rate, amount of $\mathrm{OH} \cdot$, COD removal, TOC removal and BOD removal, et al., ought to be measured at certain given times;

3. microelements/trace elements that exist in natural water can be chosen as target substances. A point must be emphasized here is that initial concentration of target substance in treatment of simulated wastewater should on basis of original concentration; and,

4. real wastewater with complex components and high COD value $(>1000 \mathrm{mg} / \mathrm{L})$ can be selected as the treatment object, as it is the fundamental aim of academic research. Initial properties of effluents should be characterized before studies undertaken.

Author Contributions: Project administration, B.W.; Writing—original draft preparation, X.X.; Writing一review and editing, K.T. and H.Z..; Comments and suggestions, B.W.; Data curation, W.Z.

Funding: This work was carried out with the financial supports of the National Science and Technology Major Project of China (2016ZX05062).

Conflicts of Interest: The authors declare no conflict of interest. 


\section{References}

1. Nawrocki, J.; Kasprzyk-Hordern, B. The efficiency and mechanisms of catalytic ozonation. Appl. Catal. B Environ. 2010, 99, 27-42. [CrossRef]

2. Boczkaj, G.; Fernandes, A. Wastewater treatment by means of advanced oxidation processes at basic $\mathrm{pH}$ conditions: A review. Chem. Eng. J. 2017, 320, 608-633. [CrossRef]

3. Yang, T.T.; Peng, J.M.; Zheng, Y.; He, X.; Hou, Y.D.; Wu, L.; Fu, X.Z. Enhanced photocatalytic ozonation degradation of organic pollutants by $\mathrm{ZnO}$ modified $\mathrm{TiO}_{2}$ nanocomposites. Appl. Catal. B Environ. 2018, 221, 223-234. [CrossRef]

4. Merle, T.; Pronk, W.; Gunten, U.V. MEMBRO3X-A Novel combination of a Membrane Contactor with Advanced Oxidation $\left(\mathrm{O}_{3} / \mathrm{H}_{2} \mathrm{O}_{2}\right)$ for Simultaneous Micropollutant Abatement and Bromate minimization. Environ. Sci. Technol. Lett. 2017, 4, 180-185. [CrossRef]

5. Lucas, M.S.; Reis, N.M.; Puma, G.L. Intensification of ozonation processes in a novel, compact, multi-orifice oscillatory baffled column. Chem. Eng. J. 2016, 296, 335-339. [CrossRef]

6. Liu, H.L.; Cheng, F.Q.; Wang, D.S. Interaction of ozone and organic matter in coagulation with inorganic polymer flocculant-PACl: Role of organic components. Desalination 2009, 249, 596-601. [CrossRef]

7. Shangguan, Y.; Yu, S.; Gong, C.; Wang, Y.; Yang, W.; Hou, L. A Review of Microbubble and its Applications in Ozonation. IOP Conf. Ser. 2018, 128, 012149. [CrossRef]

8. Stylianou, S.K.; Kostoglou, M.; Zouboulis, A.I. Ozone Mass Transfer Studies in a Hydrophobized Ceramic Membrane Contactor: Experiments and Analysis. Ind. Eng. Chem. Res. 2016, 55, 7587-7597. [CrossRef]

9. Qi, Y. Ozonation of Water and Waste Water: A Practical Guide to Understanding Ozone and Its Applications. Int. J. Environ. Stud. 2010, 67, 795-796. [CrossRef]

10. Khuntia, S.; Majumder, S.K.; Ghosh, P. Quantitative prediction of generation of hydroxyl radicals from ozone microbubbles. Chem. Eng. Res. Des. 2015, 98, 231-239. [CrossRef]

11. Bamperng, S.; Suwannachart, T.; Atchariyawut, S.; Jiraratananon, R. Ozonation of dye wastewater by membrane contactor using PVDF and PTFE membranes. Sep. Purif. Technol. 2010, 72, 186-193. [CrossRef]

12. Hollender, J.; Zimmermann, S.G.; Koepke, S.; Krauss, M.; McArdell, C.S.; Ort, C.; Singer, H.; von Gunten, U.; Siegrist, H. Elimination of Organic Micropollutants in a Municipal Wastewater Treatment Plant Upgraded with a Full-Scale Post-Ozonation Followed by Sand Filtration. Environ. Sci. Technol. 2009, 43, 7862-7869. [CrossRef] [PubMed]

13. Yu, L.; Li, Y.Y.; Yu, H.; Zhang, K.; Wang, X.W.; Chen, X.F.; Yue, J.; Huo, T.X.; Ge, H.W.; Alamry, K.A.; et al. A fluorescence probe for highly selective and sensitive detection of gaseous ozone based on excited-state intramolecular proton transfer mechanism. Sens. Actuator B Chem. 2018, 266, 717-723. [CrossRef]

14. Kim, C.S.; Alexis, N.E.; Rappold, A.G.; Kehrl, H.; Hazucha, M.J.; Lay, J.C.; Schmitt, M.T.; Case, M.; Devlin, R.B.; Peden, D.B.; et al. Lung Function and Inflammatory Responses in Healthy Young Adults Exposed to 0.06 ppm Ozone for 6.6 Hours. Am. J. Respir. Crit. Care Med. 2011, 183, 1215-1221. [CrossRef] [PubMed]

15. Yan, Y.; Krishnakumar, S.; Yu, H.; Ramishetti, S.; Deng, L.W.; Wang, S.H.; Huang, L.; Huang, D.J. Nickel(II) Dithiocarbamate Complexes Containing Sulforhodamine B as Fluorescent Probes for Selective Detection of Nitrogen Dioxide. J. Am. Chem. Soc. 2013, 135, 5312-5315. [CrossRef] [PubMed]

16. Kukuzaki, M.; Fujimoto, K.; Kai, S.; Ohe, K.; Oshima, T.; Baba, Y. Ozone mass transfer in an ozone-water contacting process with Shirasu porous glass (SPG) membranes-A comparative study of hydrophilic and hydrophobic membranes. Sep. Purif. Technol. 2010, 72, 347-356. [CrossRef]

17. Ikhlaq, A.; Brown, D.R.; Kasprzyk-Hordern, B. Mechanisms of catalytic ozonation on alumina and zeolites in water: Formation of hydroxyl radicals. Appl. Catal. B Environ. 2012, 123, 94-106. [CrossRef]

18. Tehrani-Bagha, A.R.; Mahmoodi, N.M.; Menger, F.M. Degradation of a persistent organic dye from colored textile wastewater by ozonation. Desalination 2010, 260, 34-38. [CrossRef]

19. Zhang, T.; Croue, J.P. Catalytic ozonation not relying on hydroxyl radical oxidation: A selective and competitive reaction process related to metal-carboxylate complexes. Appl. Catal. B Environ. 2014, 144, 831-839. [CrossRef]

20. Faria, P.C.C.; Orfao, J.J.M.; Pereira, M.F.R. A novel ceria-activated carbon composite for the catalytic ozonation of carboxylic acids. Catal. Commun. 2008, 9, 2121-2126. [CrossRef]

21. Kulkarni, A.A. Mass Transfer in Bubble Column Reactors: Effect of Bubble Size Distribution. Ind. Eng. Chem. Res. 2007, 46, 2205-2211. [CrossRef] 
22. Stylianou, S.K.; Sklari, S.D.; Zamboulis, D.; Zaspalis, V.T.; Zouboulis, A.I. Development of bubble-less ozonation and membrane filtration process for the treatment of contaminated water. J. Membr. Sci. 2015, 492, 40-47. [CrossRef]

23. Shin, W.T.; Mirmiran, A.; Yiacoumi, S.; Tsouris, C. Ozonation using microbubbles formed by electric fields. Sep. Purif. Technol. 1999, 15, 271-282. [CrossRef]

24. Yao, K.N.; Chi, Y.; Wang, F.; Yan, J.H.; Ni, M.J.; Cen, K.F. The effect of microbubbles on gas-liquid mass transfer coefficient and degradation rate of COD in wastewater treatment. Water Sci. Technol. 2016, 73, 1969-1977. [CrossRef] [PubMed]

25. Agarwal, A.; Ng, W.J.; Liu, Y. Principle and applications of microbubble and nanobubble technology for water treatment. Chemosphere 2011, 84, 1175-1180. [CrossRef] [PubMed]

26. Muroyama, K.; Imai, K.; Oka, Y.; Hayashi, J. Mass transfer properties in a bubble column associated with micro-bubble dispersions. Chem. Eng. Sci. 2013, 100, 464-473. [CrossRef]

27. Serizawa, A.; Inui, T.; Yahiro, T.; Kawara, Z. Pseudo-Laminarization of Micro-Bubble Containing Milky Bubbly Flow in A Pipe. Multiph. Sci. Technol. 2003, 17, 79-101. [CrossRef]

28. Maeda, Y.; Hosokawa, S.; Baba, Y.; Tomiyama, A.; Ito, Y. Generation mechanism of micro-bubbles in a pressurized dissolution method. Exp. Therm. Fluid Sci. 2015, 60, 201-207. [CrossRef]

29. Takahashi, M. $\zeta$ Potential of Microbubbles in Aqueous Solutions: Electrical Properties of the Gas-Water Interface. J. Phys. Chem. B 2005, 109, 21858-21864. [CrossRef]

30. Masayoshi, T.; Taro, K.; Yoshitaka, Y.; Hirofumi, O.; Shouzou, H.; Hideaki, S. Effect of Shrinking Microbubble on Gas Hydrate Formation. J. Phys. Chem. B 2003, 107, 2171-2173.

31. Nawrocki, J. Catalytic ozonation in water: Controversies and questions. Discussion paper. Appl. Catal. B Environ. 2013, 142, 465-471. [CrossRef]

32. Kasprzyk-Hordern, B.; Ziółek, M.; Nawrocki, J. Catalytic ozonation and methods of enhancing molecular ozone reactions in water treatment. Appl. Catal. B Environ. 2003, 46, 639-669. [CrossRef]

33. Wei, C.H.; Zhang, F.Z.; Hu, Y.; Feng, C.H.; Wu, H.Z. Ozonation in water treatment: THE generation, basic properties of ozone and its practical application. Rev. Chem. Eng. 2017, 33, 49-89. [CrossRef]

34. Zhao, L.; Ma, W.C.; Ma, J.; Wen, G.; Liu, Q.L. Relationship between acceleration of hydroxyl radical initiation and increase of multiple-ultrasonic field amount in the process of ultrasound catalytic ozonation for degradation of nitrobenzene in aqueous solution. Ultrason. Sonochem. 2015, 22, 198-204. [CrossRef] [PubMed]

35. Xu, Z.; Mochida, K.; Naito, T.; Yasuda, K. Effects of Operational Conditions on 1,4-Dioxane Degradation by Combined Use of Ultrasound and Ozone Microbubbles. Jpn. J. Appl. Phys. 2012, 51, 07GD08. [CrossRef]

36. Liu, C.; Tanaka, H.; Zhang, J.; Zhang, L.; Yang, J.L.; Huang, X.; Kubota, N. Successful application of Shirasu porous glass (SPG) membrane system for microbubble aeration in a biofilm reactor treating synthetic wastewater. Sep. Purif. Technol. 2013, 103, 53-59. [CrossRef]

37. Kukizaki, M.; Wada, T. Effect of the membrane wettability on the size and size distribution of microbubbles formed from Shirasu-porous-glass (SPG) membranes. Colloid Surf. A 2008, 317, 146-154. [CrossRef]

38. Wattendorf, U.; Merkle, H.P. PEGylation as a Tool for the Biomedical Engineering of Surface Modified Microparticles. J. Pharm. Sci. 2008, 97, 4655-4669. [CrossRef]

39. Li, P.; Takahashi, M.; Chiba, K. Degradation of phenol by the collapse of microbubbles. Chemosphere 2009, 75, 1371-1375. [CrossRef]

40. Zimmerman, W.B.; Kokoo, R. Esterification for biodiesel production with a phantom catalyst: Bubble mediated reactive distillation. Appl. Energy 2018, 221, 28-40. [CrossRef]

41. Zheng, T.L.; Wang, Q.H.; Zhang, T.; Shi, Z.N.; Tian, Y.L.; Shi, S.S.; Smale, N.; Wang, J. Microbubble enhanced ozonation process for advanced treatment of wastewater produced in acrylic fiber manufacturing industry. J. Hazard. Mater. 2015, 287, 412-420. [CrossRef] [PubMed]

42. Sloan, E.D., Jr. Gas Hydrates: Review of Physical/Chemical Properties. Energy Fuels 1998, 12, $191-196$. [CrossRef]

43. Alain, G.; Patrice, C.; Jean, L.; Jean-Louis, S. $\zeta$ Potential at an Air-Water Surface Related to the Critical Micelle Concentration of Aqueous Mixed Surfactant Systems. Ind. Eng. Chem. Res. 2000, 39, 2677-2681.

44. Masayoshi, T.; Kaneo, C.; Pan, L. Free-Radical Generation from Collapsing Microbubbles in the Absence of a Dynamic Stimulus. J. Phys. Chem. B 2007, 111, 1343-1347. 
45. Alexander, W.; Christopher, I.; Thomas, H.; Alex, S.; William, Z.; Felipe, I.; David, L.; Hemaka, B. Dielectric Barrier Discharge Plasma Microbubble Reactor for Pretreatment of Lignocellulosic Biomass. AIChE J. 2018, 64, 3803-3816.

46. Wang, B.; Xiong, X.G.Y.; Shui, Y.Y.; Huang, Z.Y.; Tian, K. A systematic study of enhanced ozone mass transfer for ultrasonic-assisted PTFE hollow fiber membrane aeration process. Chem. Eng. J. 2019, 357, 678-688. [CrossRef]

47. Ikeura, H.; Kobayashi, F.; Tamaki, M. Removal of residual pesticides in vegetables using ozone microbubbles. J. Hazard. Mater. 2011, 186, 956-959. [CrossRef]

48. Chu, L.B.; Xing, X.H.; Yu, A.F.; Sun, X.L.; Jurcik, B. Enhanced treatment of practical textile wastewater by microbubble ozonation. Process Saf. Environ. Protect. 2008, 86, 389-393. [CrossRef]

49. Jabesa, A.; Ghosh, P. Removal of dimethyl phthalate from water by ozone microbubbles. Environ. Technol. 2017, 38, 2093-2103. [CrossRef] [PubMed]

50. Nishiyama, T.; Matsuura, K.; Sato, E.; Kometani, N.; Horibe, H. Degradation of Hydrophilic Polymers in Aqueous Solution by Using Ozone Microbubble. J. Photopolym. Sci. Technol. 2017, 30, 285-289. [CrossRef]

51. Li, P.; Wu, C.; Yang, Y.X.; Wang, Y.; Yu, S.L.; Xia, S.J.; Chu, W.H. Effects of microbubble ozonation on the formation of disinfection by-products in bromide-containing water from Tai Lake. Sep. Purif. Technol. 2018, 193, 408-414. [CrossRef]

52. Chu, L.B.; Xing, X.H.; Yu, A.F.; Zhou, Y.N.; Sun, X.L.; Jurcik, B. Enhanced ozonation of simulated dyestuff wastewater by microbubbles. Chemosphere 2007, 68, 1854-1860. [CrossRef] [PubMed]

53. Pandhal, J.; Siswanto, A.; Kuvshinov, D.; Zimmerman, W.B.; Lawtom, L.; Edwards, C. Cell Lysis and Detoxification of Cyanotoxins Using a Novel Combination of Microbubble Generation and Plasma Microreactor Technology for Ozonation. Front. Microbiol. 2018, 9, 678. [CrossRef] [PubMed]

54. Elovitz, M.S.; Gunten, U.V. Hydroxyl Radical/Ozone Ratios During Ozonation Processes. I. The Rct Concept. Ozone Sci. Eng. 1999, 21, 239-260. [CrossRef]

55. Adewuyi, Y.G. Sonochemistry: Environmental Science and Engineering Applications. Ind. Eng. Chem. Res. 2001, 40, 4681-4715. [CrossRef]

56. Mahamuni, N.N.; Adewuyi, Y.G. Advanced oxidation processes (AOPs) involving ultrasound for waste water treatment: A review with emphasis on cost estimation. Ultrason. Sonochem. 2010, 17, 990-1003. [CrossRef] [PubMed]

57. Grcic, I.; Obradovic, M.; Vujevic, D.; Koprivanac, N. Sono-Fenton oxidation of formic acid/formate ions in an aqueous solution: From an experimental design to the mechanistic modeling. Chem. Eng. J. 2010, 164, 196-207. [CrossRef]

58. Pradhan, A.A.; Gogate, P.R. Degradation of p-nitrophenol using acoustic cavitation and Fenton chemistry. J. Hazard. Mater. 2010, 173, 517-522. [CrossRef]

59. Gagol, M.; Przyjazny, A.; Boczkaj, G. Highly effective degradation of selected groups of organic compounds by cavitation based AOPs under basic $\mathrm{pH}$ conditions. Ultrason. Sonochem. 2018, 45, 257-266. [CrossRef]

60. Heisler, J.; Glibert, P.M.; Burkholder, J.M.; Anderson, D.M.; Cochlan, W.; Dennison, W.C.; Dortch, Q.; Gobler, C.J.; Heil, C.A.; Humphries, E.; et al. Eutrophication and harmful algal blooms: A scientific consensus. Harmful Algae 2008, 8, 3-13. [CrossRef]

61. Karami, N.; Mohammadi, P.; Zinadzadeh, A.; Falahi, F.; Aghamohammadi, N. High rate treatment of hospital wastewater using activated sludge process induced by high-frequency ultrasound. Ultrason. Sonochem. 2018, 46, 89-98. [CrossRef] [PubMed]

62. Jawale, R.H.; Gogate, P.R. Combined treatment approaches based on ultrasound for removal of triazophos from wastewater. Ultrason. Sonochem. 2018, 40, 89-96. [CrossRef] [PubMed]

63. Weiss, J. Radiochemistry of Aqueous Solutions. Nature 1944, 153, 748-750. [CrossRef]

64. Makino, K.; Mossoba, M.M.; Riesz, P. Chemical effects of ultrasound on aqueous solutions. Evidence for hydroxyl and hydrogen free radicals (.cntdot.OH and .cntdot.H) by spin trapping. Chem. Informationsdienst 1982, 13, 3537-3539.

65. Zuniga-Benitez, H.; Soltan, J.; Penuela, G.A. Application of ultrasound for degradation of benzophenone-3 in aqueous solutions. Int. J. Environ. Sci. Technol. 2016, 13, 77-86. [CrossRef]

66. Fitzgerald, M.E.; Griffing, V.; Sullivan, J. Chemical Effects of Ultrasonics-"Hot Spot" Chemistry. J. Chem. Phys. 1956, 25, 926-933. [CrossRef] 
67. Zangeneh, H.; Zinatizadeh, A.A.L.; Feizy, M. A comparative study on the performance of different advanced oxidation processes $\left(\mathrm{UV} / \mathrm{O}_{3} / \mathrm{H}_{2} \mathrm{O}_{2}\right)$ treating linear alkyl benzene (LAB) production plant's wastewater. J. Ind. Eng. Chem. 2014, 20, 1453-1461. [CrossRef]

68. Ince, N.H. Ultrasound-assisted advanced oxidation processes for water decontamination. Ultrason. Sonochem. 2018, 40, 97-103. [CrossRef]

69. Suslick, K.S.; Crum, L.A. Sonochemistry and Sonoluminescence. J. Acoust. Soc. Am. 2001, 109, 2346.

70. Kidak, R.; Dogan, S. Medium-high frequency ultrasound and ozone based advanced oxidation for amoxicillin removal in water. Ultrason. Sonochem. 2018, 40, 131-139. [CrossRef]

71. Hamdaoui, O.; Naffrechoux, E. Sonochemical and photosonochemical degradation of 4-chlorophenol in aqueous media. Ultrason. Sonochem. 2008, 15, 981-987. [CrossRef]

72. Jyoti, K.K.; Pandit, A.B. Ozone and cavitation for water disinfection. Biochem. Eng. J. 2004, 18, 9-19. [CrossRef]

73. Flint, E.B.; Suslick, K.S. The Temperature of Cavitation. Science 1991, 253, 1397-1399. [CrossRef]

74. Ciawi, E.; Rae, J.; Ashokkumar, M.; Franz, G. Determination of temperatures within acoustically generated bubbles in aqueous solutions at different ultrasound frequencies. J. Phys. Chem B. 2006, 110, 13656-13660. [CrossRef] [PubMed]

75. Avvaru, B.; Venkateswaran, N.; Uppara, P.; Iyengar, S.B.; Katti, S.S. Current knowledge and potential applications of cavitation technologies for the petroleum industry. Ultrason. Sonochem. 2018, 42, 493-507. [CrossRef] [PubMed]

76. Suslick, K.S. The Site of Sonochemical Reactions. IEEE Trans. Ultrason. Ferroelectr. 1986, 33, $143-147$. [CrossRef]

77. Suslick, K.S.; Hammerton, D.A.; Cline, R.E. Sonochemical hot spot. J. Am. Chem. Soc. 1986, 108, 5641-5642. [CrossRef]

78. Weavers, L.K.; Hoffmann, M.R. Sonolytic Decomposition of Ozone in Aqueous Solution: Mass Transfer Effects. Environ. Sci. Technol. 1998, 32, 3941-3947. [CrossRef]

79. Mason, T.J.; Joyce, S.S.; Phull, S.S.; Lorimer, J.P. Potential uses of ultrasound in the biological decontamination of water. Ultrason. Sonochem. 2003, 10, 319-323. [CrossRef]

80. Patil, P.N.; Gogate, P.R. Degradation of dichlorvos using hybrid advanced oxidation processes based on ultrasound. J. Water Process. Eng. 2015, 8, E58-E65. [CrossRef]

81. Boczkaj, G.; Gagol, M.; Klein, M.; Przyjazny, A. Effective method of treatment of effluents from production of bitumens under basic $\mathrm{pH}$ conditions using hydrodynamic cavitation aided by external oxidants. Ultrason. Sonochem. 2018, 40, 969-979. [CrossRef] [PubMed]

82. Zhang, H.; Duan, L.; Zhang, D. Absorption kinetics of ozone in water with ultrasonic radiation. Ultrason. Sonochem. 2007, 14, 552-556. [CrossRef] [PubMed]

83. Gogate, P.R.; Mededovic-Thagard, S.; McGuire, D.; Chapas, G.; Blackmon, J.; Cathey, R. Hybrid reactor based on combined cavitation and ozonation: From concept to practical reality. Ultrason. Sonochem. 2014, 21, 590-598. [CrossRef] [PubMed]

84. He, Z.; Song, S.; Zhou, H.; Ying, H.; Chen, J.C.I. Reactive Black 5 decolorization by combined sonolysis and ozonation. Ultrason. Sonochem. 2007, 14, 298-304. [CrossRef] [PubMed]

85. Shen, Y.J.; Xu, Q.H.; Wei, R.R.; Ma, J.L.; Wang, Y. Mechanism and dynamic study of reactive red X-3B dye degradation by ultrasonic-assisted ozone oxidation process. Ultrason. Sonochem. 2017, 38, 681-692. [CrossRef] [PubMed]

86. Al-Hashimi, A.M.; Mason, T.J.; Joyce, E.M. Combined Effect of Ultrasound and Ozone on Bacteria in Water. Environ. Sci. Technol. 2015, 49, 11697-11702. [CrossRef] [PubMed]

87. Ji, G.D.; Zhang, B.L.; Wu, Y.C. Combined ultrasound/ozone degradation of carbazole in APG(1214) surfactant solution. J. Hazard. Mater. 2012, 225, 1-7. [CrossRef] [PubMed]

88. Guo, W.Q.; Yin, R.L.; Zhou, X.J.; Cao, H.O.; Chang, J.S.; Ren, N.Q. Ultrasonic-assisted ozone oxidation process for sulfamethoxazole removal: IMPACT factors and degradation process. Desalin. Water Treat. 2016, 57, 21015-21022. [CrossRef]

89. Wang, B.; Zhu, C.P.; Gong, R.H.; Zhu, J.; Huang, B.; Xu, F.; Ren, Q.G.; Han, Q.B.; He, Z.B. Degradation of acephate using combined ultrasonic and ozonation method. Water Sci. Eng. 2015, 8, 233-238. [CrossRef] 
90. Afzal, S.; Quan, X.; Zhang, J.L. High surface area mesoporous nanocast $\mathrm{LaMO}_{3}(\mathrm{M}=\mathrm{Mn}, \mathrm{Fe})$ perovskites for efficient catalytic ozonation and an insight into probable catalytic mechanism. Appl. Catal. B Environ. 2017, 206, 692-703. [CrossRef]

91. Wang, Y.; Yang, W.; Yin, X.; Liu, Y. The role of Mn-doping for catalytic ozonation of phenol using $\mathrm{Mn} / \gamma-\mathrm{Al}_{2} \mathrm{O}_{3}$ nanocatalyst: Performance and mechanism. J. Environ. Chem. Eng. 2016, 4, 3415-3425. [CrossRef]

92. Zhao, L.; Sun, Z.Z.; Ma, J.; Liu, H.L. Enhancement Mechanism of Heterogeneous Catalytic Ozonation by Cordierite-Supported Copper for the Degradation of Nitrobenzene in Aqueous Solution. Environ. Sci. Technol. 2009, 43, 2047-2053. [CrossRef] [PubMed]

93. Graham, N.; Jiang, C.C.; Li, X.Z.; Jiang, J.Q.; Jun, M. The influence of pH on the degradation of phenol and chlorophenols by potassium ferrate. Chemosphere 2004, 56, 949-956. [CrossRef] [PubMed]

94. Asgari, G.; Mohammadi, A.S.; Mortazavi, S.B.; Ramavandi, B. Investigation on the pyrolysis of cow bone as a catalyst for ozone aqueous decomposition: Kinetic approach. J. Anal. Appl. Pyrolysis 2013, 99, 149-154. [CrossRef]

95. Wang, J.L.; Bai, Z.Y. Fe-based catalysts for heterogeneous catalytic ozonation of emerging contaminants in water and wastewater. Chem. Eng. J. 2017, 312, 79-98. [CrossRef]

96. Jawale, R.H.; Tandale, A.; Gogate, P.R. Novel approaches based on ultrasound for treatment of wastewater containing potassium ferrocyanide. Ultrason. Sonochem. 2017, 38, 402-409. [CrossRef] [PubMed]

97. Mehrjouei, M.; Muller, S.; Moller, D. A review on photocatalytic ozonation used for the treatment of water and wastewater. Chem. Eng. J. 2015, 263, 209-219. [CrossRef]

98. Huang, R.H.; Yan, H.H.; Li, L.S.; Deng, D.Y.; Shu, Y.H.; Zhang, Q.Y. Catalytic activity of Fe/SBA-15 for ozonation of dimethyl phthalate in aqueous solution. Appl. Catal. B Environ. 2011, 106, 264-271. [CrossRef]

99. Goel, M.; Hongqiang, H.; Mujumdar, A.S.; Ray, B.M. Sonochemical decomposition of volatile and non-volatile organic compounds-A comparative study. Water Res. 2004, 38, 4247-4261. [CrossRef]

100. Golash, N.; Gogate, P.R. Degradation of dichlorvos containing wastewaters using sonochemical reactors. Ultrason. Sonochem. 2012, 19, 1051-1060. [CrossRef]

101. Lan, B.Y.; Huang, R.H.; Li, L.S.; Yan, H.H.; Liao, G.Z.; Wang, X.; Zhang, Q.Y. Catalytic ozonation of p-chlorobenzoic acid in aqueous solution using Fe-MCM-41 as catalyst. Chem. Eng. J. 2013, 219, 346-354. [CrossRef]

102. Yan, H.H.; Lu, P.; Pan, Z.Q.; Wang, X.; Zhang, Q.Y.; Li, L.S. Ce/SBA-15 as a heterogeneous ozonation catalyst for efficient mineralization of dimethyl phthalate. J. Mol. Catal. A Chem. 2013, 377, 57-64. [CrossRef]

103. Panda, D.; Manickam, S. Recent advancements in the sonophotocatalysis (SPC) and doped-sonophotocatalysis (DSPC) for the treatment of recalcitrant hazardous organic water pollutants. Ultrason. Sonochem. 2017, 36, 481-496. [CrossRef] [PubMed]

104. Mason, T.J.; Peters, D. Practical Sonochemistry. In Power Ultrasound Uses and Applications, 2nd ed.; Ellis Horwood Publishers: Chichester, UK, 2002.

105. Merouani, S.; Hamdaoui, O.; Saoudi, F.; Chiha, M. Sonochemical degradation of Rhodamine B in aqueous phase: Effects of additives. Chem. Eng. J. 2010, 158, 550-557. [CrossRef]

106. Zhou, X.Q.; Zhao, J.Y.; Li, Z.F.; Song, J.N.; Li, X.Y.; Yang, X.; Wang, D.L. Enhancement effects of ultrasound on secondary wastewater effluent disinfection by sodium hypochlorite and disinfection by-products analysis. Ultrason. Sonochem. 2016, 29, 60-66. [CrossRef] [PubMed]

107. Jagannathan, M.; Grieser, F.; Ashokkumar, M. Sonophotocatalytic degradation of paracetamol using $\mathrm{TiO}_{2}$ and $\mathrm{Fe}^{3+}$. Sep. Purif. Technol. 2013, 103, 114-118. [CrossRef]

108. Madhavan, J.; Grieser, F.; Ashokkumar, M. Combined advanced oxidation processes for the synergistic degradation of ibuprofen in aqueous environments. J. Hazard. Mater. 2010, 178, 202-208. [CrossRef] [PubMed]

109. Madhavan, J.; Sathishkumar, P.; Anandan, S.; Grieser, F.; Ashokkumar, M. Degradation of acid red 88 by the combination of sonolysis and photocatalysis. Sep. Purif. Technol. 2010, 74, 336-341. [CrossRef]

110. Lv, A.H.; Hu, C.; Nie, Y.L.; Qu, J.H. Catalytic ozonation of toxic pollutants over magnetic cobalt and manganese co-doped gamma- $\mathrm{Fe}_{2} \mathrm{O}_{3}$. Appl. Catal. B Environ. 2010, 100, 62-67. [CrossRef]

(C) 2018 by the authors. Licensee MDPI, Basel, Switzerland. This article is an open access article distributed under the terms and conditions of the Creative Commons Attribution (CC BY) license (http:/ / creativecommons.org/licenses/by/4.0/). 